\title{
Can Mobile Phones Improve Agricultural Outcomes? Evidence from a Randomized Experiment in Niger
}

\author{
Jenny C. Aker ${ }^{\mathrm{a}, \mathrm{b}}$, Christopher Ksoll ${ }^{\mathrm{c},{ }^{*}}$
}

a Tufts University, The Fletcher School, 112 Packard Avenue, Medford, MA, 02155, USA; Jenny.Aker@tufts.edu
b Center for Global Development, 1800 Massachusetts Avenue NW, Third Floor, Washington DC 20036, USA
c University of Ottawa, School of International Development and Global Studies, Ottawa, 120 University, Ottawa ON
K1N6N5, Canada; cksoll@uottawa.ca
${ }^{\mathrm{d}}$ Centre for the Study of African Economies, University of Oxford, Manor Road, Oxford OX1 3UQ, United Kingdom

\begin{abstract}
* Aker: Tufts University, The Fletcher School, 112 Packard Avenue, Medford, MA, 02155, USA; Jenny.Aker@tufts.edu; Ksoll: School of International Development and Global Studies, Ottawa, 120 University, Ottawa ON K1N6N5, Canada; cksoll@uottawa.ca. We thank two referees for their comments. We are indebted to Catholic Relief Services (CRS) Niger for their support in all stages of this project and would especially like to acknowledge the contributions of Ali Abdoulaye, Aichatou Bety, Saley Boukari, Mahamane Laouali Moussa, Ousseini Sountalma, Lisa Washington-Sow and the entire CRS/Niger staff. Rachel Cassidy, Elizabeth Yepsen, Amanda Meng provided excellent research assistance. We are grateful for financial support from the Blum Center for Developing Economies (UC-Berkeley), CITRIS, the University of Oxford, the Hitachi Center and the Gates Foundation. None of the funding sources were involved in the implementation of the research. All errors are our own.
\end{abstract}




\title{
Can Mobile Phones Improve Agricultural Outcomes? Evidence from a Randomized Experiment in Niger
}

February 2015

\begin{abstract}
The widespread growth of mobile phone coverage worldwide has offered new potential for increasing rural households' access to information and public and private transfers. Yet despite the proliferation of mobile phone-based interventions in the agricultural sector, there is mixed evidence on their impact. We report the results of a randomized evaluation in Niger, in which rural households increased their access to information technology and their capacity to use it. We find that households in treated villages planted a more diverse basket of crops, particularly marginal cash crops grown by women. This did not increase the likelihood of selling these crops or the farm-gate price received, suggesting that other market failures need to be addressed to improve farmers' welfare.
\end{abstract}

Keywords: Agricultural prices; Sen's entitlement framework; ICT; mobile phones; program evaluation; Niger

JEL Codes: O1, O3 


\section{Introduction}

In developing countries, informal networks provide important means by which households and individuals share information on a variety of topics, although the costs of searching for this information are often high. Economists and policymakers alike have proposed a number of reasons for this costly search, including limited transport and telecommunications infrastructure. These costs make it difficult for households and individuals to engage in optimal arbitrage, resulting in excess price dispersion and potentially lower prices (for farmers) and higher prices (for consumers). Policymakers and development practitioners alike have attempted to address these information asymmetries and "trade entitlement failures" for agricultural households (Sen, 1976, 1981; Dreze and Sen, 1995) through promoting agricultural extension systems or market information services (MIS). Despite decades of investment in such programs, evidence of their impact on household welfare is mixed, possibly due to the irrelevancy or untimeliness of the information provided (Aker, 2010).

The widespread growth of mobile phone coverage over the past decade provides new opportunities to overcome these search and transaction costs, and the potential to improve welfare. In sub-Saharan Africa, it is estimated that over 60 percent of the population has access to mobile phone coverage, with 356 million unique phone subscribers (Wireless Intelligence 2012). Mobile phones could reduce households' costs of searching for private information, especially as compared with traditional mechanisms, such as personal travel, newspapers or landlines. Similarly, they could improve farmers' access to public information by reducing the marginal cost of providing extension services or improving the timeliness of such information. Finally, with the introduction of mobile money services, mobile phones could improve farmers' 
access to private and public transfers, thereby allowing them to obtain access to credit when and where it's needed or to respond to shocks.

We report the results of a randomized evaluation in Niger, in which individuals were provided with access to shared mobile phones and learned how to use them, all in the context of an adult education program entitled Project ABC. In related work, Aker et al. (2012) showed that this program increased students' learning outcomes in both the short- and long-term. Yet in that work, we did not measure the impact of this program on other measures of well-being.

Overall, our results suggest that improved access to mobile phone technology, as well as learning how to use it, generates some economic benefits in rural agricultural settings for specific populations. We find that households in $\mathrm{ABC}$ villages planted more diversified crops as compared with their non-mobile phone counterparts. In particular, households were more likely to grow okra, a marginal cash crop grown by women. These effects were stronger among households that had not previously owned a mobile phone and where a female was the primary beneficiary, as well as among households living in villages where a market was not present. Households were also more likely to engage in sales of crops, though average quantities sold did not increase.

Prior evidence on the effect of information technology on entitlements, agricultural outcomes or food security is mixed. Goyal (2010) finds that the rollout of internet kiosks providing price information and quality-testing in India resulted in higher soybean prices for farmers. Jensen (2007) finds that the introduction of mobile phone coverage increased fishermen's sales prices and reduced their losses. Aker and Fafchamps (2014) find that the rollout of mobile phone coverage reduced farm-gate price dispersion in Niger, but did not affect 
farm-gate prices. Fafchamps and Minten (2012) find that while a mobile phone-based price and weather information system in India increased farmers' access to information and crop grading, it had no effect on other agricultural outcomes, including farm-gate prices. Camacho and Conover (2011) found similar effects of a SMS-based weather and price information system in Colombia. Only Cole and Fernando (2012) found that participating in a voice-based agricultural extension system affected farmers' input use and yields for some crops.

While seemingly contradictory, there is little theoretical reason to believe that access to mobile phone technology would lead to changes in agricultural behavior or an increase in farmgate prices in all countries for all crops. If markets are well-integrated, then improved access to information would have no impact. However, if markets are poorly integrated, potentially due to high search costs, then improved access to information via information technology could allow farmers to bargain for higher prices, thereby creating incentives to use different inputs or produce more diverse crops. Yet even if arbitrage opportunities exist, improved access to information might not result in economic benefits for agricultural populations if markets are uncompetitive or if credit market failures exist. ${ }^{1}$ Our findings indicate that improved access to information technology changes households' production decisions, but does not lead to a substantial improvement in economic benefits (which could lead to improved endowments and entitlements). Our findings are consistent with an environment where these other market failures might constrain households' production and consumption choices and entitlements.

\footnotetext{
${ }^{1}$ In some cases the extent of these market failures will depend upon the perishability of a good. Goods that are more perishable are likely to be traded more locally and are likely to exhibit more temporal and spatial variation. While a reduction in search costs might reduce this variation, it could also extend the radius in which transportation is profitable more for non-perishable goods. As a result, the theoretical predictions with respect to the impact of ICT on price dispersion for perishable and non-perishable goods are ambiguous.
} 
The remainder of the paper is organized as follows: Section 2 provides background information on agricultural production and marketing in Niger, as well as information on the intervention and experimental design. Section 3 describes the data and estimation strategy. Section 4 presents the results, whereas Section 5 discusses alternative explanations and potential mechanisms. Section 6 concludes.

\section{Research Setting and Design}

With a per capita GNP of US\$230 and an estimated 85 percent of the population living on less than US\$2 per day, Niger is one of the lowest-ranked countries on the United Nations' Human Development Index (UNDP 2014). As the country spans the Saharan, Sahelian and Sudano-Sahelian agro-ecological zones, rainfall ranges from 200 millimeters $(\mathrm{mm})$ per year in the north to $800 \mathrm{~mm}$ in the south. Precipitation varies substantially on an intra- and inter-annual basis (Nicholson, Some and Kone, 2000). For example, Niger experienced six droughts between 1980 and 2005 (Government of Niger 2007). Inter-annual deviations in rainfall are positively associated with fluctuations in agricultural output, as yields depend upon the timing and quantity of rainfall.

A majority of households in Niger depend upon rainfed agriculture, with staple food crops consisting of millet, sorghum and fonio, and cash crops including cowpea, peanuts, cotton and sesame. Most agricultural products in Niger are traded through a system of national markets, each of which is held on a weekly basis. On average, farmers live $10 \mathrm{~km}$ from the nearest market. Transport and search costs are quite high, in part due to the limited infrastructure: only 8 percent of roads are paved, and there are fewer than .2 landlines for every 100 people. Access to public information by way of agricultural extension services is similarly limited, with one 
extension agent for every 20,000 people (IFPRI 2012). While women play an important role in the agricultural production and marketing process, particularly for marginal cash crops, women often have fewer opportunities to travel to markets and sell their output.

\subsection{Intervention}

Between 2009 and 2011, an international non-governmental organization, Catholic Relief Services (CRS), implemented an adult education program in two rural regions of Niger. The intervention provided eight months of basic literacy and numeracy skills in the native language of the village. Conforming to the norms of the Ministry of Non-Formal Education, each village had a separate literacy class by gender, made up of 25 students.

As a modification to the basic adult education program, a "mobile phone module" was added to the program, called ABC (Aker et al 2012). As outlined in Aker et al (2012), the ABC program taught students how to use a simple mobile phone and distributed a shared mobile phone (worth US\$ 5) to a group of five students. The module was introduced into the classes three months after the start of the adult education program, and students did not have additional class time.

\subsection{Experimental Design}

CRS identified 140 villages in Niger prior to the start of the adult education program. Among these villages, some already had an existing adult education program or did not have mobile phone coverage, which reduced the sample to 113 villages. Villages were first stratified by administrative division before being randomly assigned to a year cohort (e.g., 2009 or 2010), and were then assigned to either the basic (non- $A B C$ ) or mobile-phone "enhanced" (ABC) adult 
education program. Fifty-eight villages were assigned to the $\mathrm{ABC}$ intervention and 55 to the non-ABC intervention (Aker et al 2012).

Eligible students were identified for both cohorts during the baseline. Individual-level eligibility was determined by whether the individual was illiterate, willing to participate in the program and a member of a formal or informal village-level producers' association. If there were more than fifty eligible applicants in a village, students were randomly chosen from among all eligible applicants in a public lottery.

By comparing outcomes of those households in $\mathrm{ABC}$ versus non- $\mathrm{ABC}$ villages, we can estimate the causal effect of the mobile phone module on agricultural production and prices of agricultural goods as compared to the standard adult education intervention. Since the ABC program involved distributing shared mobile phones and teaching students how to use these phones, we cannot disentangle the impact of the technology from learning how to use the technology.

\subsection{Conceptual Framework}

Sen's entitlement approach maps households' endowments into "entitlements" (Sen 1976, 1981, Dreze and Sen 1989). In an agricultural context such as Niger, the primary endowments are land, labor and livestock, whereas entitlements are households' consumption possibilities generated by producing and selling agricultural goods (and labor). The feasible consumption bundles available to a household not only depend upon households' endowments, but also their trade and production exchanges. An essential component of trade exchanges are farm-gate and consumers' prices. These prices are, in turn, affected by individuals' and 
households' search and transport costs, although such costs are typically not the focus of the analysis.

As mentioned previously, Niger is subject to frequent droughts, harvest failures, food crises and famines. Famines and extreme food insecurity are the result of two possible failures: a “direct entitlement failure," whereby households have too few endowments to meet their food needs; or a "trade entitlement failure," whereby households face high consumer prices or low farm-gate prices and wages (Sen 1981, Dreze and Sen 1989). Both of these failures are, in turn, affected by high search costs: If farmers' search costs are too high, this can increase price dispersion and lower the prices that they receive for their goods or labor. These high search costs can similarly affect farmers' production choices: High search costs might result in higher input prices and suboptimal input use or encourage farmers to produce less risky crops.

The introduction of mobile phone technology could potentially affect households' endowments - as well as their production and trade entitlements, and hence their agricultural outcomes and well-being - in a number of ways. First, mobile phones could potentially reduce farmers' search costs, thereby allowing them to obtain price information in a greater number of markets and sell in the market with the highest price net of transport costs (Tack and Aker 2014). Second, in the absence of selling in a different market, improved access to information could potentially improve farmers' bargaining position vis-à-vis traders, thereby allowing them to negotiate a higher sales price. Third, mobile technology could potentially allow farmers to conclude a sale using a mobile phone, thereby reducing uncertainty associated with selling in a distant market (Aker and Mbiti 2010). Fourth, if information technology increases the prices that farmers receive, and agricultural production is price elastic, then this would increase the production of such commodities in the future. 
The potential impacts of information technology on agricultural outcomes depend upon a variety of assumptions. In general, farmers are more likely to benefit when search costs are the primary reason for price dispersion or trade entitlement failures, rather than other market failures, such as credit constraints or uncompetitive markets. Second, even in the presence of these other market failures, the impact of information technology could depend upon the market structure for a given crop and the crop's perishability.

\section{Data and Empirical Strategy}

\subsection{Data}

The data we use in this paper come from two primary sources. First, we conducted a household survey with 1,044 adult education students across 95 villages in the CRS program. The survey respondents were chosen by random sampling after stratifying by village and gender sub-groups. A baseline survey was conducted in January 2009, with follow-up surveys in January 2010 (the midterm) and January 2011. Each survey collected information on household demographics, assets, production and sales activities, access to price information, migration and mobile phone ownership and usage. Of the 1,044 households interviewed at baseline, only 31 did not complete the midline survey and 14 did not complete the endline, suggesting that attrition is not a primary concern.

Our second data source is village-level surveys, which were conducted in each village at the same time as the household surveys. Village-level surveys were conducted with a focus group of key informants at the village level, and conducted information on village-level infrastructure (roads, markets, mobile phone coverage) and migration. 
Table 1 compares the means of outcomes and covariates in $\mathrm{ABC}$ and non-ABC villages prior to the program. Overall, the table suggests that the randomization was successful in creating similar groups along most dimensions. Average household size was eight, with thirtypercent of households owning a mobile phone prior to the program. Households cultivated an average of five different crops, primarily millet, sorghum and cowpea, and over 60 percent of households experienced a drought in the year prior to the survey. The one area where there was a difference was in market access: Households in $\mathrm{ABC}$ villages were 15 percentage points more likely to have access to a market in their village, with a statistically significant difference between the two. Overall, we made over 50 comparisons and found that any statistically significant differences were what we would expect with a randomized design. However, as market access could be correlated with treatment and our outcomes of interest, we separately conduct the analysis by presence of a market in the village as a robustness check.

\subsection{Estimation Strategy}

To estimate the impact of the $\mathrm{ABC}$ program on a variety of outcomes, we use a difference-in-differences specification, comparing outcomes of households in the $\mathrm{ABC}$ and non$\mathrm{ABC}$ villages before and after the program. This takes the following form:

$$
\begin{aligned}
Y_{i v t}=\beta_{0}+\beta_{1} \text { mobile }_{v t}+\beta_{2} \text { literacy }_{v t} & +\beta_{3} \text { mobile }_{v t} \text { literacy }_{v t}+\beta_{4}{\text { cohort } 10_{v}}_{v}+\mathbf{X}_{i v}^{\prime} \gamma+\theta_{R} \\
& +\theta_{t}+\varepsilon_{i v t}
\end{aligned}
$$

The variable $Y_{i v}$ is defined as the outcome of interest (the types of crops planted, the quantity produced, the quantity sold and the price received) for household or individual $i$ in village $v$. Mobile $_{v}$ is a binary variable equal to 1 if the village was ever assigned the $\mathrm{ABC}$ program, 0 otherwise. literacy $y_{v t}$ is a binary variable equal to one after the village participated in the literacy 
program (either in 2010 or 2011). cohort10 is a binary variable that denotes whether the village received the literacy program in 2009 or $2010 . X_{i v}$ is a vector of time-invariant household variables, whereas $\theta_{R}$ are stratification fixed effects. We also control for different survey rounds. The primary coefficient of interest is $\beta_{3}$, which captures the impact being assigned to a village with the $\mathrm{ABC}$ program, as compared to participating in a simple adult education program. ${ }^{2}$ This is the so-called intent-to-treat (ITT) effect, i.e. the impact of being in a village assigned to the $\mathrm{ABC}$ program, which is preferable in the presence of imperfect compliance or within-village spillovers. The error term $\varepsilon_{i v t}$ captures unobserved student ability or idiosyncratic shocks. We cluster the error term at the village level for all specifications. In the Tables we present results for the coefficient of interest, $\beta_{3}$.

As an alternative to equation (1), we also estimate the simple difference in means between the $\mathrm{ABC}$ and non- $\mathrm{ABC}$ villages after the program. We also modify the above equation to estimate the impact of the adult education program by comparing outcomes of those in the 2009 cohort (as compared with those in the 2010 cohort) after the first year of the program.

\section{Results}

\subsection{Average Effects}

Table 2 first presents the results from a simple difference regression of farmers' crop choices, as measured by the number of crops cultivated during the previous agricultural season

\footnotetext{
${ }^{2}$ This estimation regression differs from a simple difference regression that is often used in randomized control trials, which would specific an interaction of mobile * post, because the post dummy is perfectly collinear with the literacy treatment. Put differently, there was no fourth treatment group that received mobiles without receiving the literacy program. As such the post period for the mobile intervention is the same as having benefitted from access to the literacy program.
} 
on a dummy for having received the $\mathrm{ABC}$ program. Households in the $\mathrm{ABC}$ villages cultivated .18 more crops as compared with their non-ABC counterparts, with a statistically significant difference at the 10 percent level (Table 2, Column 1). Using a difference-in-differences specification from equation (1), we find that farm households living in ABC villages cultivated .34 more crops as compared to their non-ABC counterparts, with a statistically significant difference at the 1 percent level (Column 2). Results are similar when controlling for villagelevel fixed effects (Column 3). Overall, this change represents an eight percent increase in the number of crops cultivated as compared to the mean of non-ABC households during the baseline.

Table $3 \mathrm{~A}$ provides some evidence on the ways in which the $\mathrm{ABC}$ program affected the types of crops grown. Overall, the ABC program did not increase the likelihood of households cultivating most staple food and cash crops, such as millet, sorghum, cowpea or sesame. However, households in the $\mathrm{ABC}$ villages were 9 percentage points more likely to cultivate okra than those in non-ABC villages, with a statistically significant difference at the 1 percent level.

While farmers' increased the diversity of crop choices (the extensive margin), a natural question is whether they also increased the quantity produced. An analysis of the impact of the program on farmers' production (by crop) finds no effects of the program on the quantity produced (Table 3B). ${ }^{3}$

\footnotetext{
${ }^{3}$ The absence of an impact on the quantity produced could be due, in part, to the imprecision of our estimates and due to a severe drought in Niger 2009, which had a strong negative impact on agricultural production. There was a strong decline in the quantity of crops grown in non-ABC villages between 2009 and 2010.
} 
While the $\mathrm{ABC}$ program affected farm households' crop choices, a key question is whether this affected farm households' marketing behavior. Tables $4 \mathrm{~A}$ and $4 \mathrm{~B}$ present the regression results using a variety of agricultural marketing outcomes. There is some evidence that the program increased farm households' likelihood of selling crops, in particular millet and voandzhou, though these increases are only statistically at the 10 percent level of significance (Table 4A). It also did not, however, increase the average quantity that households sold for any of the crops (Table 4B). Thus, this suggests that while the program increased the likelihood of producing certain crops (namely okra) and the likelihood of selling others (millet and voandzhou), it did not appear to affect the quantity sold.

\subsection{Heterogeneous Effects}

We might expect differential benefits among subpopulations for whom complementarities between agriculture and technology are stronger, such as those who have differential access to markets or information technology. Tables 5A-5E test for heterogeneous impacts of the $\mathrm{ABC}$ program by the household's residence, gender, baseline mobile phone ownership and access to a market.

The Dosso region is relatively closer to the capital city (Niamey), as well as to the border of Nigeria, and has a higher concentration of agricultural markets and more households engaged in agricultural trade. The $\mathrm{ABC}$ program could therefore be more useful in the Dosso region, as farmers might have had a stronger incentive to use mobile phones to obtain price information. Table 5A reports the results of both simple differences and double difference specifications for the $\mathrm{ABC}$ program by geographic region, with Dosso in Columns 1-3 and Zinder in Columns 4-6. Overall, the analysis suggests that the impact of the program is stronger in the Dosso region. 
Using a simple difference specification (Column 1), households in $A B C$ villages planted an average of .34 more crops as compared with those in non-ABC villages, with a statistically significant difference at the 1 percent level. These results are stronger once using a DD specification, increasing to .43 (Columns 2 and 3). While the number of crops cultivated in $\mathrm{ABC}$ villages was also higher in Zinder (Columns 4-6), the effect is not statistically difference from zero for all specifications. Nevertheless, there is not a statistically significant difference of the impact of the program between the Dosso and Zinder regions.

Tables 5B and 5C disaggregates these effects by gender, focusing on whether the man or woman in the household participated in the program. The analysis suggests that the impact of the program occurred primarily among women participants: Households in $\mathrm{ABC}$ villages with female literacy participants produced .24 to .46 more types of crops, with a statistically significant effect at conventional levels (Table 5B, Columns 1-3). While ABC households with male literacy participants also cultivated more types of crops, this is not a statistically significant effect. Looking at the types of crops cultivated (Table 5C), we find that women in $\mathrm{ABC}$ villages were 7 percentage points more likely to produce peanuts, 12 percentage points more like to produce okra and 8 percentage points more likely to produce vouandzou, or Bambara groundnut, with a statistically significant effect at the 10,1 and 10 percent levels, respectively.

As 30 percent of households owned mobile phones prior to baseline, it would be reasonable to assume that the impact of the program might differ by previous mobile phone ownership. For example, households who previously owned a mobile phone might already have market contacts, and be better able to take advantage of the new technology. Conversely, households without prior access might benefit more strongly from being able to search more quickly for information. Table 5D investigates the impact by baseline mobile phone ownership. 
Overall, households who owned mobile phones during the baseline and lived in $\mathrm{ABC}$ villages increased the number of crops grown by .29 to .76 crops, with a statistically significant impact at the 5 and 1 percent levels, respectively (Columns 1-3). Those households who had not previously owned a mobile phone also increased the number of crops grown by .12 to .14, although the effect is not statistically significant at conventional levels (Columns 4-6). The impact of the ABC program by baseline mobile phone ownership is statistically significant. This suggests that the learning component of the mobile phone curriculum - i.e., learning how to use the mobile phone - may have been more crucial than improving access to the shared mobile phone.

Table 5E studies the impact by access to a market within the village. Using a DD specification, the $\mathrm{ABC}$ program had no impact on the types of crops grown among those households with access to a market within the village (Column 1-3). However, households in $\mathrm{ABC}$ villages without access to the market increased the number of crops grown by .30 to .39 , with a statistically significant difference at the 5 percent level. ${ }^{4}$ For households with market access the point estimates for the number of crops grown are also positive, but the impact is not statistically significant.

A possible concern with the heterogeneity analysis is that the various "traits" we study (region, gender, mobile phone ownership and market access) are not randomly assigned. Thus, these characteristics could be correlated with unobservable factors. While we cannot entirely rule

\footnotetext{
${ }^{4}$ The simple difference estimates, however, suggest that the impacts are larger in villages with baseline market. We prefer the village fixed effect and difference-in-difference specifications since they control for more unobservable determinants of the number of crops.
} 
out that the heterogeneous treatment effects we observe are due to some unobservable heterogeneity in other traits correlated, the heterogeneity in treatment effects along the three traits seems reasonable.

Table 6 investigates whether marketing behavior changed. We do not find any evidence that farmers increased the number of markets they went to, received a higher price for okra or voandzhou, followed price information, nor used mobile phones to obtain price information.

\section{Alternative Explanations}

Collective action can also be an important dimension in trading agricultural products (Aoki and Hayami 2001). While some of the villages had pre-existing producer associations, these were typically not involved in sales. One of the aims of the CRS program was to set up producer associations, as well as to improve the market linkages. CRS undertook these activities in both the treatment and control villages. It is unclear as to whether the effect of information and communications technology (ICT) would be larger: If producer associations cooperated to use mobile phones, then mobile phones can have larger impacts in villages with producer associations than in villages where there are no producer associations. However, if producer associations were somewhat effective at centralizing information acquisition and information dissemination even before mobile phones, then the additional impact of mobile phones might well be less than in a context where there are no producer associations and mobile phones provide a huge increase to information.

\section{Discussion and Conclusion}


The results in this paper suggest that farmers who receive access to a joint mobile phone and learn how to use it increase the number of types of crops grown, primarily by increasing their production of marginal cash crops. There is also evidence to suggest that they are more likely to engage in selling two crops. There are no statistically significant impacts on the quantity grown or the quantity sold of each crop, so the increase in the number of crops grown and the likelihood of selling any amount will not translate on average into major improvements in household's well-being. When put into the context of Sen's framework, on average we do not find that providing access to mobile phones and teaching people how to use them improved their exchange entitlements.

This general conclusion hides some heterogeneity: households in which women participated in the literacy program are the ones driving the increase in the number of crops grown (even though impacts on sales are insignificant). Households with a market at baseline do not increase the number of crops grown, suggesting that farmers in villages with markets are already sufficiently well-informed about prices, and that such an intervention does not matter. Households that did have a market at baseline do increase the number of crops grown. Interestingly, the impact is much stronger among households who owned mobile phones at baseline, suggesting that access to phones was less important than learning how to use them. The impacts exist only in Dosso, which is the more densely populated and more fertile area.

The patterns of effects for the number of crops grown certainly suggests that impacts of ICT will not be uniform everywhere. It suggests that learning how to use the mobile phones was more important than actual access. Future interventions planning to employ ICT to raise farmer's well-being need to think carefully whom to target, in which villages (for example non-market villages), which crops, and how. 


\section{REFERENCES}

Aker, J.C., 2008. Does Digital Divide or Provide? Information Technology, Search Costs and Cereal Market Performance in Niger. BREAD Working Paper No. 177.

Aker, J.C., 2010. Information from Markets near and Far: Mobile Phones and Agricultural Markets in Niger. Am. Econ. J.: Appl. Econ. 2 (3), 46-59.

Aker, J. C., Fafchamps, M., 2014. "Mobile Phone Coverage and Producer Markets: Evidence from West Africa." World Bank Economic Review (forthcoming).

Aker, J.C., Ksoll, C., Lybbert, T.J., 2012. Can Mobile Phones Improve Learning? Evidence from a Field Experiment in Niger. Am. Econ. J.: Appl. Econ. 4 (4), 94-120.

Aker, J.C., Mbiti, I.M., 2010. Mobile Phones and Economic Development in Africa. J. Econ. Perspect. 24 (3), 207-32.

Aoki, M., Hayami, Y. (eds), 2001. Community and Markets in Economic Development, Oxford University Press, Oxford.

Camacho, A., Conover, E., 2011. The Impact of Receiving Price and Climate Information in the Agricultural Sector. IDB Working Paper, 220.

Cole, S., Fernando, A.N., 2012. The Value of Advice: Evidence from Mobile Phone-Based Agricultural Extension. Harvard Business School Working Paper 13-047.

Dreze, J., Sen, A., 1989. Hunger and Public Action. Clarendon Press, Oxford.

Dreze, J., Sen, A., 1995. The Political Economy of Hunger. Clarendon Press, Oxford.

Fafchamps, M., Minten, B., 2012. Impact of SMS-Based Agricultural Information on Indian Farmers. 26(3): 383-414. World Bank Econ. Rev.

Government of Niger. 2007. Plan National de Contingence: Volet Sécurité Alimentaire et Nutritionnelle. Niamey, Niger.

Goyal, A., 2010. Information, Direct Access to Farmers, and Rural Market Performance in Central India. Am. Econ. J.: Appl. Econ. 2 (3), 22-45.

IFPRI, 2012. Direction Générale de l'Environnement et des Eaux de Forêts. Agricultural Extension and Advisory Services Worldwide. Accessed under http://www.worldwideextension.org/africa/niger/direction-generale.

Jensen, R., 2007. The Digital Provide: Information (Technology), Market Performance, and Welfare in the South Indian Fisheries Sector. Q. J. Econ. 122 (3), 879-924.

Nicholson, S. E., Some, B. and Kone, B., 2000: An Analysis of Recent Rainfall Conditions in West Africa, Including the Rainy Seasons of the 1997 El Niño and the 1998 La Niña Years. J. Climate, 13, 2628-2640. 
Pratt, J.W., Wise, D.A., Zeckhauser, R., 1979. Price Differences in Almost Competitive Markets. Q. J. Econ. 93 (2), 189-211.

Sen, A. 1976. Famines as Failures of Exchange Entitlements. Econ. Polit. Wkly. 11 (31/33), Special Number: Population and Poverty, 1273-1280.

Sen, A., 1981. Ingredients of Famine Analysis: Availability and Entitlements. Q. J. Econ. 96 (3), 433-464.

Tack, J.B., Aker, J.C., 2014. Information, Mobile Telephony and Traders' Search Behavior. Working Paper.

United Nations Development Programme, 2014. Hum. Dev. Rep. 2014. United Nations Development Programme, New York.

Wireless Intelligence, 2012. Summary of Report on Global Mobile Penetration - Subscribers versus connections. Accessed under http://www.gsma.com/newsroom/press-release/gsmaannounces-new-global-research-that-highlights-significant-growth-opportunity-for-the$\underline{\text { mobile-industry/ }}$ 
Table 1: Baseline Descriptive Statistics

\begin{tabular}{|c|c|c|c|}
\hline & $\begin{array}{c}\text { ABC } \\
\text { Mean }\end{array}$ & $\begin{array}{l}\text { Non- } \\
\text { ABC } \\
\text { Mean }\end{array}$ & $\begin{array}{c}\text { Difference } \\
\text { ABC-non- } \\
\text { ABC }\end{array}$ \\
\hline \multicolumn{4}{|l|}{ Panel A: Socio-Demographic Characteristics } \\
\hline Age of respondent (in years) & 37.146 & 37.892 & $-0.407(0.936)$ \\
\hline Number of household members & 8.319 & 8.431 & $0.009(0.256)$ \\
\hline Number of adult household members & 3.913 & 4.108 & $-0.121(0.141)$ \\
\hline Number of female household members & 4.131 & 4.151 & $0.038(0.137)$ \\
\hline Percent children with education & 0.268 & 0.279 & $0.000(0.018)$ \\
\hline Percent adults with education & 0.302 & 0.317 & $-0.013(0.021)$ \\
\hline Number of asset categories owned & 4.979 & 4.990 & $-0.031(0.097)$ \\
\hline Household owns mobile phone $(1=$ Yes, $0=$ No) & 0.295 & 0.297 & $-0.003(0.027)$ \\
\hline Respondent has access to mobile phone & 0.795 & 0.762 & $0.042(0.022)^{*}$ \\
\hline Used mobile to talk about trade in Niger & 0.092 & 0.105 & $-0.007(0.022)$ \\
\hline Respondent is member of village level association & 0.640 & 0.634 & $0.008(0.026)$ \\
\hline \multicolumn{4}{|l|}{ Panel B: Agro-Pastoral Production } \\
\hline Household experienced drought in past year & 0.612 & 0.643 & $-0.055(0.044)$ \\
\hline Farming is respondent's primary occupation & 0.862 & 0.880 & $-0.019(0.016)$ \\
\hline Respondent member of a farmers' association & 0.407 & 0.356 & $0.048(0.033)$ \\
\hline Household received training in agricultural marketing & 0.042 & 0.033 & $0.014(0.011)$ \\
\hline Number of agricultural crops cultivated in past season & 5.500 & 5.616 & $-0.025(0.113)$ \\
\hline Livestock is a source of household income & 0.9 & 0.900 & $0.000(0.017)$ \\
\hline Number of livestock categories owned by household & 3.177 & 3.121 & $0.053(0.074)$ \\
\hline Household has sold livestock since previous harvest & 0.583 & 0.542 & $0.059(0.029) * *$ \\
\hline \multicolumn{4}{|l|}{ Panel B: Agro-Pastoral Marketing } \\
\hline Village has any market & 0.330 & 0.170 & $0.154(0.090) *$ \\
\hline Village has a livestock market & 0.210 & 0.150 & $0.045(0.079)$ \\
\hline Nobs (households) & 521 & 520 & \\
\hline Nobs (villages) & 48 & 47 & \\
\hline \multicolumn{4}{|c|}{$\begin{array}{l}\text { Notes: Column } 1 \text { presents the mean for ABC villages, Column } 2 \text { presents the mean for non-ABC } \\
\text { villages. Column } 3 \text { reports the coefficient from a regression of the dependent variable on an } \\
\text { indicator variable for ABC and sub-region fixed effects to account for randomization. Thus, Column } \\
\text { (3) is not exactly equal to the difference between Columns } 1 \text { and } 2 \text {. Results are robust to omitting } \\
\text { the sub-region fixed effects. Huber-White standard errors clustered at the village level presented } \\
\text { in parentheses. }{ }^{* * *}, * *, * \text { denote statistical significance at the } 1,5,10 \text { percent levels, respectively. }\end{array}$} \\
\hline
\end{tabular}


Table 2: Average Program Effects on Number of Crops Grown

(1)

(2)

(3)

Mobile * Literacy

$0.18^{*}$

$(0.10)$

$0.34^{* * *}$

$(0.12)$

$0.27^{* *}$

Baseline Mean

5.56

5.56

5.56

Controls

Yes

Yes

Yes

Sub-region fixed effects

Yes

Yes

No

Village fixed effects

No

No

Yes

Number of observations

1,502

2,991

2,991

$\mathrm{R}^{2}$

0.13

0.18

0.23

Notes: Column 1 presents results from a simple difference regression which includes data for January 2010 for the cohort receiving the literacy program in 2010 and for 2011 for both cohorts. Columns 2 and 3 present results from difference in difference regressions. Controls include dummies for gender, cohort, year (all columns), as well as whether the village had received the literacy program that year (Columns $2 \& 3$ ) and whether the village was an ABC village (only in Column 2 - it is subsumed in the village fixed effects in Column 3, and is identical to the treatment dummy in the case of Column 1) Sub-regional fixed effects control for the level of randomization. ${ }^{* * *},{ }^{* *}, *$ denote statistical significance at the 1,5 and 10 percent levels, respectively. Robust standard errors clustered at the village level. 


\section{Table 3A: Impact of ABC Program on Likelihood of Growing Specific Crops}

\begin{tabular}{|c|c|c|c|c|c|c|c|}
\hline & Millet & Sorghum & Cowpea & Oseille & Peanut & Okra & Vouandzou \\
\hline Mobile * Literacy & $\begin{array}{c}0.00 \\
(0.00)\end{array}$ & $\begin{array}{l}-0.00 \\
(0.03)\end{array}$ & $\begin{array}{c}0.02 \\
(0.01)\end{array}$ & $\begin{array}{c}0.04 \\
(0.03)\end{array}$ & $\begin{array}{c}0.03 \\
(0.04)\end{array}$ & $\begin{array}{c}0.09^{* * * *} \\
(0.03)\end{array}$ & $\begin{array}{c}0.04 \\
(0.04)\end{array}$ \\
\hline Controls & Yes & Yes & Yes & Yes & Yes & Yes & Yes \\
\hline $\begin{array}{l}\text { Sub-region fixed effects } \\
\text { Number of }\end{array}$ & Yes & Yes & Yes & Yes & Yes & Yes & Yes \\
\hline observations & 2,991 & 2,991 & 2,991 & 2,991 & 2,991 & 2,991 & 2,991 \\
\hline $\mathrm{R}^{2}$ & 0.01 & 0.08 & 0.04 & 0.09 & 0.25 & 0.16 & 0.23 \\
\hline
\end{tabular}

\section{Table 3B: Impact of ABC Program on Quantity Produced of Specific Crops}

\begin{tabular}{cccccccc}
\hline \hline & Millet & Sorghum & Cowpea & Oseille & Peanut & Okra & Vouandzou \\
\cline { 2 - 8 } Mobile * Literacy & 193.62 & -7.16 & 13.84 & -11.90 & 2.33 & 4.02 & 15.42 \\
& $(133.28)$ & $(18.87)$ & $(16.45)$ & $(7.33)$ & $(21.79)$ & $(2.76)$ & $(13.11)$ \\
Controls & Yes & Yes & Yes & Yes & Yes & Yes & Yes \\
Sub-region fixed effects & Yes & Yes & Yes & Yes & Yes & Yes & Yes \\
$\begin{array}{c}\text { Number of } \\
\text { observations }\end{array}$ & 2,991 & 2,991 & 2,991 & 2,991 & 2,991 & 2,991 & 2,991 \\
$\mathrm{R}^{2}$ & 0.18 & 0.07 & 0.19 & 0.15 & 0.34 & 0.14 & 0.33 \\
\hline
\end{tabular}

Notes: The table present results from difference in difference regressions, following the specification of Table 2, Column 2. Sub-regional fixed effects control for the level of randomization. ${ }^{* * *}, * *, *$ denote statistical significance at the 1,5 and 10 percent levels, respectively. Robust standard errors clustered at the village level. 
Table 4A: Impact of the ABC Program on the Likelihood of Selling Commodities

\begin{tabular}{cccccccc}
\hline \hline & Millet & Sorghum & Cowpea & Oseille & Peanut & Okra & Vouandzou \\
\cline { 2 - 8 } Mobile * Literacy & $0.07^{*}$ & 0.04 & 0.03 & 0.01 & 0.02 & 0.02 & $0.04^{*}$ \\
& $(0.04)$ & $(0.02)$ & $(0.04)$ & $(0.02)$ & $(0.03)$ & $(0.02)$ & $(0.03)$ \\
Controls & Yes & Yes & Yes & Yes & Yes & Yes & Yes \\
Sub-region fixed effects & Yes & Yes & Yes & Yes & Yes & Yes & Yes \\
Number of observations & 2,991 & 2,991 & 2,991 & 2,991 & 2,991 & 2,991 & 2,991 \\
$\mathrm{R}^{2}$ & 0.12 & 0.08 & 0.17 & 0.10 & 0.31 & 0.20 & 0.24 \\
\hline
\end{tabular}

Notes: The table present results from difference in difference regressions, following the specification of Table 2, Column 2. Sub-regional fixed effects control for the level of randomization. ${ }^{* * *}, * *$, * denote statistical significance at the 1,5 and 10 percent levels, respectively. Robust standard errors clustered at the village level.

\section{Table 4B: Impact of the ABC Program on the Quantity Sold}

\begin{tabular}{cccccccc}
\hline \hline & & & & & & & \\
Mobile * Literacy & 14.42 & 3.31 & 10.26 & -0.54 & 9.79 & 1.22 & 8.51 \\
& $(15.67)$ & $(2.06)$ & $(9.53)$ & $(3.62)$ & $(13.16)$ & $(0.95)$ & $(5.19)$ \\
Controls & Yes & Yes & Yes & Yes & Yes & Yes & Yes \\
Sub-region fixed effects & Yes & Yes & Yes & Yes & Yes & Yes & Yes \\
Number of observations & 2,991 & 2,991 & 2,991 & 2,991 & 2,991 & 2,991 & 2,991 \\
$R^{2}$ & 0.05 & 0.06 & 0.16 & 0.07 & 0.25 & 0.15 & 0.16 \\
\hline
\end{tabular}

Notes: The table present results from difference in difference regressions, following the specification of Table 2, Column 2. Sub-regional fixed effects control for the level of randomization. ***, **, * denote statistical significance at the 1,5 and 10 percent levels, respectively. Robust standard errors clustered at the village level. 


\section{Table 5A: Number of crops grown by region}

\begin{tabular}{|c|c|c|c|c|c|c|}
\hline \multirow[b]{3}{*}{ Mobile * Literacy } & \multicolumn{3}{|c|}{ Dosso } & \multicolumn{3}{|c|}{ Zinder } \\
\hline & $(1)$ & $(2)$ & $(3)$ & $(4)$ & $(5)$ & (6) \\
\hline & $\begin{array}{l}0.34^{* *} \\
(0.13)\end{array}$ & $\begin{array}{c}0.43 * * * \\
(0.13)\end{array}$ & $\begin{array}{c}0.42^{* * *} \\
(0.14)\end{array}$ & $\begin{array}{l}-0.01 \\
(0.16)\end{array}$ & $\begin{array}{c}0.23 \\
(0.20)\end{array}$ & $\begin{array}{c}0.10 \\
(0.19)\end{array}$ \\
\hline Controls & Yes & Yes & Yes & Yes & Yes & Yes \\
\hline Sub-region fixed effects & Yes & Yes & No & Yes & Yes & No \\
\hline Village fixed effects & No & No & Yes & No & No & Yes \\
\hline Number of observations & 777 & 1,558 & 1,558 & 725 & 1,433 & 1,433 \\
\hline $\mathrm{R}^{2}$ & 0.10 & 0.12 & 0.18 & 0.18 & 0.25 & 0.31 \\
\hline
\end{tabular}

Table 5B: Number of crops grown by gender

\begin{tabular}{|c|c|c|c|c|c|c|}
\hline \multirow{3}{*}{ Mobile * Literacy } & \multicolumn{3}{|c|}{ Females } & \multicolumn{3}{|c|}{ Males } \\
\hline & (1) & (2) & (3) & (4) & (5) & (6) \\
\hline & $\begin{array}{l}0.22^{*} \\
(0.13)\end{array}$ & $\begin{array}{c}0.46^{* * *} \\
(0.16)\end{array}$ & $\begin{array}{c}0.38 * * \\
(0.17)\end{array}$ & $\begin{array}{c}0.10 \\
(0.14)\end{array}$ & $\begin{array}{c}0.19 \\
(0.16)\end{array}$ & $\begin{array}{c}0.14 \\
(0.16)\end{array}$ \\
\hline Controls & Yes & Yes & Yes & Yes & Yes & Yes \\
\hline Sub-region fixed effects & Yes & Yes & No & Yes & Yes & No \\
\hline Village fixed effects & No & No & Yes & No & No & Yes \\
\hline Number of observations & 779 & 1,523 & 1,523 & 723 & 1,468 & 1,468 \\
\hline $\mathrm{R}^{2}$ & 0.15 & 0.19 & 0.27 & 0.13 & 0.18 & 0.26 \\
\hline \multicolumn{7}{|c|}{$\begin{array}{l}\text { Notes: Columns } 1-3 \text { report results for households chosen for the female class of the literacy } \\
\text { program. Columns } 4-6 \text { for households chosen for the female class of the literacy program. } \\
\text { Specifications otherwise as in Table } 2 . * * * * *, * \text { denote statistical significance at the } 1,5 \text { and } \\
10 \text { percent levels, respectively. Robust standard errors clustered at the village level. }\end{array}$} \\
\hline
\end{tabular}


Table 5C: Impact of ABC Program on Likelihood of Growing Specific Crop for Females

\begin{tabular}{|c|c|c|c|c|c|c|c|}
\hline & Millet & Sorghum & Cowpea & Oseille & Peanut & Okra & Vouandzou \\
\hline Mobile * Literacy & $\begin{array}{c}0.01 \\
(0.01)\end{array}$ & $\begin{array}{c}0.01 \\
(0.04)\end{array}$ & $\begin{array}{c}0.02 \\
(0.02)\end{array}$ & $\begin{array}{c}0.05 \\
(0.04)\end{array}$ & $\begin{array}{l}0.07^{*} \\
(0.04)\end{array}$ & $\begin{array}{c}0.12^{* * * *} \\
(0.05)\end{array}$ & $\begin{array}{l}0.08^{*} \\
(0.04)\end{array}$ \\
\hline Female Respondent only & Yes & Yes & Yes & Yes & Yes & Yes & Yes \\
\hline Controls & Yes & Yes & Yes & Yes & Yes & Yes & Yes \\
\hline Sub-region fixed effects & Yes & Yes & Yes & Yes & Yes & Yes & Yes \\
\hline Number of observations & 1,523 & 1,523 & 1,523 & 1,523 & 1,523 & 1,523 & 1,523 \\
\hline $\mathrm{R}^{2}$ & 0.02 & 0.07 & 0.05 & 0.10 & 0.29 & 0.16 & 0.31 \\
\hline
\end{tabular}

Table 5D: Number of crops grown by baseline phone ownership

\begin{tabular}{ccccccc}
\hline \hline & \multicolumn{3}{c}{ Baseline cellphone } & \multicolumn{3}{c}{ No baseline cellphone } \\
& \multicolumn{1}{c}{$(1)$} & $(2)$ & $(3)$ & $(4)$ & $(5)$ & $(6)$ \\
\cline { 2 - 7 } Mobile * Literacy & $0.29^{* *}$ & $0.76^{* * *}$ & $0.62^{* * *}$ & 0.14 & 0.15 & 0.12 \\
& $(0.14)$ & $(0.20)$ & $(0.21)$ & $(0.13)$ & $(0.14)$ & $(0.15)$ \\
Controls & Yes & Yes & Yes & Yes & Yes & Yes \\
Sub-region fixed effects & Yes & Yes & No & Yes & Yes & No \\
Village fixed effects & No & No & Yes & No & No & Yes \\
Number of observations & 437 & 881 & 881 & 1,061 & 2,101 & 2,101 \\
$\mathrm{R}^{2}$ & 0.19 & 0.2 & 0.33 & 0.13 & 0.18 & 0.25 \\
\hline
\end{tabular}

Notes: Columns 1-3 report results for households who owned cellphone at baseline. Columns 4-6 for households who did not own cellphone at baseline. Specifications otherwise as in Table 2. $* * *, * *, *$ denote statistical significance at the 1,5 and 10 percent levels, respectively. Robust standard errors clustered at the village level. 
Table 5E: Number of crops grown by market in village (baseline)

\begin{tabular}{ccccccc}
\hline \hline & \multicolumn{3}{c}{ Market } & \multicolumn{3}{c}{ No Market } \\
\cline { 2 - 7 } Mobile * Literacy & $0.40^{* * *}$ & 0.09 & 0.20 & 0.15 & $0.39^{* *}$ & $0.30^{*}$ \\
& $(0.14)$ & $(0.19)$ & $(0.21)$ & $(0.12)$ & $(0.15)$ & $(0.16)$ \\
Controls & & & & & & \\
& Yes & Yes & Yes & Yes & Yes & Yes \\
Sub-region fixed effects & Yes & Yes & No & Yes & Yes & No \\
Village fixed effects & No & No & Yes & No & No & Yes \\
Number of observations & 361 & 758 & 758 & 1,141 & 2,233 & 2,233 \\
$\mathrm{R}^{2}$ & 0.19 & 0.21 & 0.23 & 0.14 & 0.19 & 0.24 \\
\hline
\end{tabular}

Notes: Columns 1-3 report results for households in villages with a market (at baseline). Columns 4-6 for households who did not own cellphone at baseline. Specifications otherwise as in Table 2. ***, **,* denote statistical significance at the 1,5 and 10 percent levels, respectively. Robust standard errors clustered at the village level.

\section{Table 6: Impact of the ABC Program on Marketing Behavior}

\begin{tabular}{|c|c|c|c|c|c|c|}
\hline Dependent variable: & $\begin{array}{c}\text { Number } \\
\text { of sales } \\
\text { markets } \\
\end{array}$ & $\begin{array}{l}\text { Number of } \\
\text { sales } \\
\text { market for } \\
\text { cash crops }\end{array}$ & $\begin{array}{c}\text { Price } \\
\text { received } \\
\text { for okra } \\
\end{array}$ & $\begin{array}{c}\text { Price } \\
\text { received } \\
\text { for } \\
\text { voandzou }\end{array}$ & $\begin{array}{c}\text { Followed } \\
\text { price } \\
\text { information }\end{array}$ & $\begin{array}{l}\text { Used mobile } \\
\text { to get price } \\
\text { information }\end{array}$ \\
\hline Mobile * Literacy & $\begin{array}{c}0.09 \\
(0.11)\end{array}$ & $\begin{array}{c}0.15 \\
(0.12)\end{array}$ & $\begin{array}{c}7.60 \\
(11.12)\end{array}$ & $\begin{array}{c}27.36 \\
(28.83)\end{array}$ & $\begin{array}{l}-0.03 \\
(0.03)\end{array}$ & $\begin{array}{c}0.01 \\
(0.01)\end{array}$ \\
\hline Controls & Yes & Yes & Yes & Yes & Yes & Yes \\
\hline Sub-region fixed effects & Yes & Yes & Yes & Yes & Yes & Yes \\
\hline Number of observations & 2,991 & 2,991 & 2,991 & 2,991 & 2,991 & 2,991 \\
\hline $\mathrm{R}^{2}$ & 0.49 & 0.39 & 0.10 & 0.02 & 0.03 & 0.05 \\
\hline \multicolumn{7}{|c|}{$\begin{array}{l}\text { Notes: The table present results from difference in difference regressions, following the specification } \\
\text { of Table 2, Column } 2 \text {. Values of zero imputed for missing observations. Sub-regional fixed effects } \\
\text { control for the level of randomization. } * * * * *, * \text { denote statistical significance at the } 1,5 \text { and } 10 \\
\text { percent levels, respectively. Robust standard errors clustered at the village level. }\end{array}$} \\
\hline
\end{tabular}


Table A1: Baseline Outcomes: Descriptive Statistics

\begin{tabular}{|c|c|c|c|}
\hline & $\begin{array}{l}\mathrm{ABC} \\
\text { Mean }\end{array}$ & $\begin{array}{c}\text { Non- } \\
\text { ABC } \\
\text { Mean }\end{array}$ & $\begin{array}{c}\text { Difference } \\
\text { ABC-non-ABC }\end{array}$ \\
\hline \multicolumn{4}{|l|}{ General outcomes } \\
\hline $\begin{array}{l}\text { Number of agricultural crops cultivated } \\
\text { in past season }\end{array}$ & 5.500 & 5.616 & $-0.025(0.113)$ \\
\hline Number of markets visited last week & 2.288 & 2.405 & $-0.077(0.097)$ \\
\hline Number of cash crop markets visited & 2.671 & 2.700 & $0.009(0.112)$ \\
\hline Market price Gombo & 260.400 & 259.574 & $18.192(18.171)$ \\
\hline Market price Voandzhou & 217.213 & 345.406 & $-146.572(145.114)$ \\
\hline $\mathrm{HH}$ follows market prices & 0.743 & 0.759 & $-0.017(0.027)$ \\
\hline \multicolumn{4}{|l|}{ Production } \\
\hline Millet & 0.992 & 1.000 & $-0.006(0.004)^{*}$ \\
\hline Sorghum & 0.799 & 0.781 & $0.014(0.025)$ \\
\hline Cowpea & 0.942 & 0.95 & $0.000(0.013)$ \\
\hline Oseille & 0.656 & 0.68 & $-0.018(0.032)$ \\
\hline Peanut & 0.552 & 0.569 & $0.000(0.035)$ \\
\hline Gombo & 0.554 & 0.614 & $-0.057(0.028)^{* *}$ \\
\hline Vouandzhou & 0.653 & 0.672 & $0.014(0.03)$ \\
\hline \multicolumn{4}{|l|}{ Sales } \\
\hline Millet & 0.352 & 0.361 & $-0.013(0.029)$ \\
\hline Sorghum & 0.089 & 0.090 & $0.010(0.022)$ \\
\hline Cowpea & 0.662 & 0.743 & $-0.061(0.031)^{* *}$ \\
\hline Oseille & 0.176 & 0.197 & $-0.013(0.330)$ \\
\hline Peanut & 0.469 & 0.505 & $-0.036(0.040)$ \\
\hline Gombo & 0.226 & 0.272 & $-0.052(0.039)$ \\
\hline Vouandzhou & 0.26 & 0.341 & $-0.082(0.033)^{* *}$ \\
\hline \multicolumn{4}{|l|}{ Quantity sold } \\
\hline Millet & 192.235 & 185.934 & $39.031(29.097)$ \\
\hline Sorghum & 65.101 & 63.571 & $7.624(12.490)$ \\
\hline Cowpea & 164.533 & 162.111 & $10.65(16.317)$ \\
\hline Oseille & 110.917 & 78.478 & $16.756(16.626)$ \\
\hline Peanut & 373.692 & 350.612 & $-14.184(53.261)$ \\
\hline Gombo & 24.742 & 37.064 & $-7.630(5.857)$ \\
\hline Vouandzhou & 116.733 & 141.368 & $-22.584(20.250)$ \\
\hline \multicolumn{4}{|c|}{$\begin{array}{l}\text { Notes: Column } 1 \text { presents the mean for } \mathrm{ABC} \text { villages, Column } 2 \text { presents the mean for non-ABC } \\
\text { villages. Column } 3 \text { reports the coefficient from a regression of the dependent variable on an indicator } \\
\text { variable for } \mathrm{ABC} \text { and sub-region fixed effects to account for randomization. Thus, Column (3) is not } \\
\text { exactly equal to the difference between Columns } 1 \text { and } 2 \text {. Results are robust to omitting the sub- } \\
\text { region fixed effects. Huber-White standard errors clustered at the village level presented in } \\
\text { parentheses. } * * *, * * * \text { denote statistical significance at the } 1,5,10 \text { percent levels, respectively. }\end{array}$} \\
\hline
\end{tabular}

